\title{
Improving Visual Spatial Ability of Children 3-4 Years Through Playing Lego
}

\author{
D A Sari' ${ }^{1}$ S Rahmatunnisa ${ }^{2,} M$ Bahfen $^{3}$ Fauziah $^{4}$ \\ $\left\{\right.$ 1'diah_mursil@yahoo.com, ${ }^{2}$ sriyantirahmatunnisa@yahoo.com, ${ }^{3}$ munifah.bahfen@yahoo.com' \\ ${ }^{4}$ fauziahapaw@gmail.com\} \\ 1,2,3 Universitas Muhammadiyah Jakarta, Indonesia \\ ${ }^{4}$ TK Lazuardi Cordova Kindergarten, Meruya Selatan,West Jakarta, Indonesia
}

\begin{abstract}
At the children aged 3-4 years stage of development, they can distinguish colors, sizes and recognize direction. This study aimed to improve the visual spatial of 3-4 year olds through play lego, carried out on 14 children in Lazuardi Cordova Kindergarten, South Meruya, West Jakarta, Indonesia. The research method used the Classroom Action Research method, which consists of planning, action, observation, and reflection. Sources of the data retrieval came from activity observation notes with an ordinal rating scale. From the results of pre-cycle research found that children's visual spatial ability was $44.2 \%$, at a score of 1.8 or was at an undeveloped level. At the implementation phase of cycle 1 , it increased of $20.4 \%$ to $64.6 \%$. It was at a score of 2.3 or was at the stage of developing. In cycle 2 the children's visual spatial ability again increased to $72.6 \%$, a score of 2.8 or in the stage began to develop. Finally in cycle 3 the child's visual spatial ability reached a very good development level of $82.2 \%$, at a score of 3.3 or at a very good development level. So it can be concluded that the visual spatial intelligence of children aged 3-4 years can be improved through playing lego.
\end{abstract}

Keywords: visual spatial ability, children aged 3-4 years, playing Lego

\section{INTRODUCTION}

Early childhood is a golden period for children's development. At this time the child's growth will affect and determine the child's development at a later stage [1]. With the increasing of parents understanding about the importance of education from an early age, many parents have begun to joined their children in to playgroups. Playgroup is an educational service for 3-4 years early childhood [2]. At pre-school age children are expected to master a variety of concepts such as colors, sizes, shapes, and directions as a foundation of learning in writing, language, mathematics and other sciences. By introduction of concepts carried out while playing, children will feel happy and without realizing they have many learning [3]. In addition, because children 3-4 years aged still think according to their own perspective (egocentric), children still need to be guided to know what is right and wrong according to the circumstances they should, not only based on their point of view. At the age of 3-4 years children begin to recognize shapes such as circles or squares, recognize colors and can distinguish sizes such as large-small, high-low, many and few, and distinguish directions such as right-left, top-bottom, front and back. The ability related to vision and spatial fields is 
called visual spatial intelligence. Children who have good visual spatial ability are able to determine the direction, as well as having good hand eye coordination [4]

In TK Lazuardi Cordova there are still many children 3-4 years aged who have not been able to distinguish colors, distinguish sizes and recognize direction. Some children still misstate directions, as right is said to be left or in the other hand left is said to be right. They also do not understand the size, such as many-little, or high-low. Playing lego is very fun for kids. Lego bricks can be builded according to their imagination and creativity, for example into a toy, or according to the shape they imagine. Therefore, can playing lego improve the visual spatial intelligence of children 3-4 years aged in kindergarten Lazuardi Cordova? How playing lego can improve children's visual spatial intelligence?

Multiple intelligences include linguistic intelligence, mathematical logic intelligence, visual spatial intelligence, intrapersonal intelligence, interpersonal intelligence, musical intelligence, kinesthetic intelligence, spiritual intelligence and naturalist intelligence ([5]. Multiple intelligence is an assessment that looks descriptively at how individuals use their intelligence to solve a problems and produce something [6]. Although up to now there has not been any measuring tool that can conclusively identify the kinds of intelligence according to Gardner's concept, but the practitioners have started to take proactive steps. The concept of multiple intelligences is studied to find as many ways as possible for the development of various intelligences in children and to apply them early on [7]. It Means there are no children who are stupid or smart, there are children who stand out in one or several types of intelligence. So in assessing and stimulating children's intelligence, parents and teachers must be as an observant in using which methods that can stimulate the potential for multiple intelligence of children [8].

Visual Spatial intelligence is one of 8 Gardner's multiple intelligences. Children with visual spatial intelligence are observers of the world, they are sensitive to natural signs and observing them visually spatially is the ability to capture the world of visual space accurately, imagine the spatial and make changes to these perceptions [9]. Visual spatial thinking ability is the ability to think in the form of visualization, images and three-dimensional forms [6]. Visual spatial intelligence is useing by children to think in the form of visualization and pictures in solving a problem or determining an answer [10]. Children who have the ability to remember places or know the positions of objects correctly, means having spatial intelligence and space intelligence [11]. Visual spatial intelligence is the ability to see an object in a great detail, and remember it for a long time [12]. Someone who has visual intelligence tends to be more creative. In addition, people who have high visual intelligence usually: 1) Have a sharp memory. 2) Can develop high thought patterns and skills in problem solving. 3) Receive awards for performance, 4) More able to express emotions and feelings [13]. Whereas in children who have high visual spatial intelligence usually: 1) Able to recognize colors and to integrate colors when coloring; 2) Like to doodle, draw, imagine, make simple designs; 3) Understand the shape and direction; 4) Able to create a form, such as the shape of a plane, house, car, or other forms that have an elaborate form of transformation Also creative, able to imagine a form, and pour it in the form of images. They are also able to estimate their distance and existence with an object. The best way to learn for children who are visually spatial is through colors, graffiti, direction, shape and space [5]. Children who stand out from the potential of visual spatial, usually have a high ability of observation and imagination and pour it in the form of images and other works [7].

Factors that influence visual spatial intelligence are nature (genetic), nurture (stimulation). Stimulation has a major role in determining the plural intelligence of a child [4]. In children 34 years aged, the basic neuron system of the child is well connected. The brain's connection 
pathways have formed strongly in associative networks. Associative networks will be expressed by children through body language, verbal and nonverbal, so that children are able to think symbolically. Symbolic thinking is thinking with the language of symbols or symbols [14]. According to Piaget, cognitive development of children aged 2-4 years is in the preoperational phase [2]. Characterized by the functioning of symbolic abilities, the ability to think intuitively, and center on the child's own perspective or egocentric [2]. Symbolic or make believe play is a preoprational period which is characterized by imaginary play and pretend play. Symbolic play is useful for combining children's emotional experiences. In subsequent developments, symbolic play activities will be increasingly constructive in the sense of being closer to reality [3]. Children aged 3 years have abundant energy and great curiosity so that it is the right time to be stimulated [15]. Children aged 3-4 years have the following characteristics of growth and development: 1). Socialization and Independence: a) Security and love. b) Encourage children to share their feelings. c) Invite children to eat together. d) Buttoned up clothes, e) Eat with your own spoon. 2). Rough Motor: Grading, Running, Jumping, Playing ball, Walking on boardwalks. 3). Fine Motor: Playing puzzles, Constructing blocks, Drawing, Cutting, Playing watercolors. 4). Speaking and Storytelling: Singing, Reading poetry, Mentioning, full name, Mentioning the opposite word, explaining something [15]. In addition, behavioral characteristics of children aged 3-4 years are: 1) Adding the use of representations that are verbal but the speech is egocentric, 2) the beginning of a symbolic period, 3) giving a transductive reason, 4) can think about something using language [14], Characteristics of children aged 3-4 years, namely recognizing and equating six colors, able to stack blocks or rings according to their shape, know their age and own name, and can tell stories using 4-5 words in one sentence [16].

Playing has a very important meaning in a child's life. Every healthy child always has the urge to play [17]. Play is a fun activity and is an inherent need in every child [3]. Teaching and learning activities in kindergartens we often hear with the slogan "learn while playing". Fun learning activities can be easily understood by early childhood. Fun learning is stimulation. The best stimulation of learning for early childhood is through play [14]. Play can also provide opportunities to give a new ideas or foster creativity [14]. The stages of early childhood play include stages: 1). Functional play (functional games), which is from simple and repetitive movements. 2). Contructive play). 3). Symbolic play (symbolic or make believe play), which is characterized by imaginary or pretend play. 4). Social play (social play with rules), at this stage children use symbols that are colored with logic and objective logic in play. Children's activities are more controlled by the rules of the game. 5). Games with rules and sports, the rules on sports are much more strict and rigid, but at this stage children like to do this activity over and over again and are motivated to achieve achievement. Early childhood will choose a game that suits their intelligence [18]. Based on research conducted by Smith and colleagues, the characteristics of play activities, namely: 1) Conducted on their own interests and interests, 2) With a happy feeling, 3) Flexible activities, 4) Freedom to choose, 5) More emphasis on the ongoing process compared to the final result, 6) Having the quality of mock. Play activities have a certain framework that separates them from daily real life [3]. When entering the age of 3 years, children will be more independent and begin to get closer to their peers. Children begin to enter the parallel playing stage, where a child plays with other children without interaction [10].

Lego is a game that using pieces of toys that can be builded into various shapes. This toy has a variety of colors, sizes and varying amounts. When preparing legos, children can recognize various shapes, sizes, and colors contained in legos so as to produce a shape [19]. Lego is a kind of toy in the form of plastic blocks which are famous among children. These 
blocks and pieces can be builded into any form, such as cars, trains, buildings, cities, statues, planes and others [20]. Playing Lego is usually introduced by parents to their children since toddlers. This game is popular because it can foster children's creativity in making something. Playing lego together with parents and children will unite ideas together. How to play lego can be done by uniting lumps into a desired shape. Bunk stacked in accordance with the size / smaller size. Because in lego there are parts that are cornered and vice versa, so that the pieces can be put together like attached. Legos can be builded according to creativity and imagination [10]. The history of LEGO begins in 1932 in Denmark: Began by Kirk Christiansen in the city of Billund (Southern Denmark) which established a game of wood crafts. To get the name of the business, he held a contest for his employees. But finally Christiansen himself who discovered the name LEGO, came from an abbreviation of two Danish words namely "Leg" and "God" which means "play well" or in German "spiel gut" means a good game. 15 years later, Christiansen found that plastic is an ideal material for toys that will be produced. So finally bought the first injection molding machine in Denmark. Thanks to its tenacity, the investment and reinvestment paid off. In 1949 Christiansen made a prototype of LEGO Brick which until now has fascinated children and adults. Year after year, he always strives to perfect LEGO Brick, which until now is still the basis of LEGO games and building systems. Starting in 1963, LEGO Brick was made from ABS (Acrylonitrile Butadine Styrene) [21].

Children who like to play lego will have good visual-spatial intelligence, because when children play lego, they pour the idea of a room concept [22]. Playing lego is including in the construction game, which is an activity that uses various objects that exist to create a work [3]. The ability of construction, as an indicator of visual spatial intelligence, can be done in various ways, including mimicking and making construction activities, playing plasticine, decorating projects and playing geometry. Making construction activities is a free construction play activity. This activity aims to stimulate the child's ability to make construction independently. All children's imagination and creativity will be devoted to making construction. Besides being able to develop construction skills, playing lego can also develop various aspects of children's potential, including cognitive, motor, language, social, and understanding the concept of space. Cognitive aspects, children are given the opportunity to re-create the images / forms of their thoughts in concrete forms. Aspects of language, developing language skills. This can be done by constructing a building, then giving it a name and discussing what is being built. Or by communicating with friends when playing lego. Social development can be seen when children work together when building legos in groups. Motor development can be seen from eye and hand coordination when arranging legos in the desired shape. Using the skills of large or rough and small or fine muscles, and controlling the placement of the object. By controlling the placement of objects children can develop visual spatial intelligence. Children understand the concept of space, train children to understand the position of objects such as above, below, right and left [5]. Lego games are constructive games that are beneficial for children to develop cognitive abilities, legos also play a role in terms of recognizing colors, because of the different colors of Lego [17].

\section{RESEARCH METHOD}

This research used classroom action research methods, Kemmis and Mc. Taggart consisting of stages (1) planning, (2) action, (3) observation, (4). Dimensions of visual spatial intelligence include: the ability to remember places, know the exact position, the ability to see an object in great detail, with indicators: can capture colors and be able to combine colors, can make simple designs, can create shapes, recognize object identities when the object exists 
from a different perspective. Can estimate the distance and whereabouts of himself with an object. The instrument used in this study was the observation guideline, which consisted of 6 indicators related to the improvement of visual spatial intelligence of children aged 3-4 years through playing lego and also documentation at the time of the study. Data analysis technique obtained through observation on a rating scale between 1 to 4 .

\section{RESULTS AND DISCUSSION}

In the pre-cycle stage, the activity was carried out in 2 meetings. At this stage the researchers only made an observations and documented children's visual spatial abilities when they played based on the instruments that had been made [23]. From the observations it can be seen that the average assement of children in this pre cycle is 1.8 on a scale of 4 , or as much as $44.2 \%$ if presented. This means that the ability of children's visual spatial intelligence in the Playgroup was still at an undeveloped stage. Furthermore, after action was given in cycle 1, cycle 2 and cycle 3 there was an increasing as can be seen in the following table.

Table 5. Recapitulation of Visual spatial Intelligence Children 3-4 years aged in TK Lazuardi Cordova, Meruya, West Jakarta, Indonesia

\begin{tabular}{|c|c|c|c|c|c|c|c|c|c|}
\hline \multirow[t]{2}{*}{ No } & \multirow{2}{*}{$\begin{array}{l}\text { Respon } \\
\text { dents }\end{array}$} & \multicolumn{2}{|c|}{ Pra Cycle } & \multicolumn{2}{|c|}{ Cycle I } & \multicolumn{2}{|c|}{ Cycle II } & \multicolumn{2}{|c|}{ Cycle III } \\
\hline & & Score & $\%$ & Score & $\%$ & Score & $\%$ & $\begin{array}{l}\text { Sco } \\
\text { re }\end{array}$ & $\%$ \\
\hline 1 & Ali & 8 & 33 & 13 & 54 & 14 & 58 & 18 & 75 \\
\hline 2 & Dar & 12 & 50 & 16 & 67 & 18 & 75 & 19 & 79 \\
\hline 3 & Sof & 14 & 58 & 20 & 83 & 22 & 92 & 23 & 96 \\
\hline 4 & Arf & 7 & 29 & 10 & 42 & 14 & 58 & 18 & 75 \\
\hline 5 & Tang & 14 & 58 & 19 & 79 & 19 & 79 & 20 & 83 \\
\hline 6 & Eva & 14 & 58 & 20 & 83 & 22 & 92 & 23 & 96 \\
\hline 7 & Aley & 7 & 29 & 10 & 42 & 13 & 54 & 17 & 71 \\
\hline 8 & Kay & 8 & 33 & 14 & 58 & 18 & 75 & 19 & 79 \\
\hline 9 & And & 11 & 46 & 15 & 63 & 17 & 71 & 19 & 79 \\
\hline 10 & Iza & 8 & 33 & 12 & 50 & 14 & 58 & 19 & 79 \\
\hline 11 & $\mathrm{Nad}$ & 8 & 33 & 14 & 58 & 15 & 63 & 18 & 75 \\
\hline 12 & Awa & 12 & 50 & 18 & 75 & 20 & 83 & 21 & 88 \\
\hline 13 & Lio & 15 & 63 & 18 & 75 & 19 & 79 & 21 & 88 \\
\hline 14 & Ney & 11 & 46 & 18 & 75 & 19 & 79 & 21 & 88 \\
\hline Tota & & 149 & 619 & 217 & 904 & 244 & 1016 & 267 & 1151 \\
\hline Ave & & & 44.2 & & 64.6 & & 72.6 & & 82.2 \\
\hline \multirow{2}{*}{\multicolumn{2}{|c|}{ Assesment }} & 1,8 & & 2,5 & & \multicolumn{2}{|l|}{2,8} & \multicolumn{2}{|l|}{3,3} \\
\hline & & \multicolumn{2}{|c|}{ Undeveloped } & \multicolumn{2}{|c|}{$\begin{array}{l}\text { Began } \\
\text { develop }\end{array}$} & \multicolumn{2}{|c|}{$\begin{array}{l}\text { Develop } \\
\text { expected }\end{array}$} & \multicolumn{2}{|c|}{$\begin{array}{l}\text { Well } \\
\text { developed }\end{array}$} \\
\hline
\end{tabular}

Graph of Visual spatial Intelligence Data Recapitulation of 3-4 years old children 


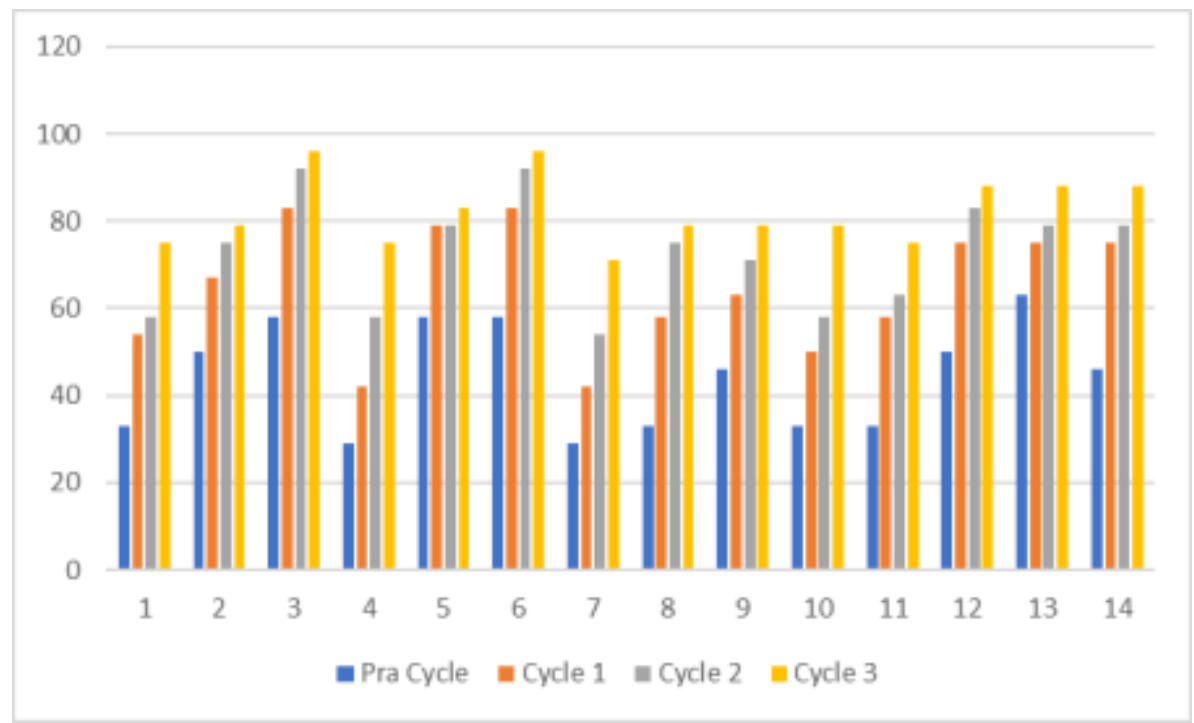

From the tables and graphs the study it was seen that efforts to improve the visual spatial abilities of children aged 3-4 years through playing lego at TK Lazuardi Cordova have been successful. Which there was an increasing in the ability of visual spatial ability of children 3-4 years aged in each cycle.

The results and process of this research were closely related to visual spatial ability according to Howard Gardner which children who have visual intelligence will be able to solve spatial problems (spatial). Children are able to observe the spatial world accurately, even imagine geometric and three-dimensional shapes, and the ability to visualize with graphics or spatial ideas (spatial).

From the observations in the pre cycle it was found that the visual spatial intelligence of children aged 3-4 years initially was at the level of rating scale 4 (at the stage of development), or by $44.2 \%$. After took action in the first cycle, an it increased of $20.4 \%$ began to occur at $64.6 \%$ or at the level of 2.5 on the 4 rating scale (at the stage of developing as expected). To improve children's visual spatial abilities, it is given another cycle II action. Where there was an increase of $8 \%$ to $72.6 \%$ or at the level of 2.8 on the rating scale 4 (stage towards developing as expected), and in cycle 3 there was an increase of $9.6 \%$ to a level of 3.3 rating scale 4 or at the Well developed stage $(82.2 \%)$. Because the visual spatial ability of children 3-4 years aged through play lego in Lazuardi Cordova Kindergarten has improved which was at a well developed stage, the Classroom Action Research was stopped in cycle 3.

\section{CONCLUSIONS}

After had the acted of playing lego for 3 cycles, it can be concluded that the activity of playing lego can improve the visual spatial ability of children 3-4 years aged in kindergarten Lazuardi Cordova. Visual spatial ability of children aged 3-4 years include the ability of children to recognize colors, grouping things according to color, re-mentioning objects seen, matched objects according to their pairs, symbolic play with surrounding objects, and mentioning the position of objects according to the information obtained (high-lace, topbottom and far-near). 


\section{REFERENCES}

[1] L. Asmawati, Pendidikan Anak Usia Dini dalam keluarga: Mendidik dengan Praktik. Jakarta: Senyum Media Press, 2009.

[2] M. Jamaris, Perkembangan dan Pengembangan Anak Usia Dini. Jakarta: PT. Gramedia Widiasarana Indonesia, 2006.

[3] M. S. Tedjasaputra, Bermain, Mainan dan Permainan. Jakarta: PT. Grasindo, 2003.

[4] M. As'adi, Panduan Praktis Stimulasi Otak Kanan. Jakarta: DIVA Press, 2010.

[5] T. Musfiroh, Pengembangan Kecerdasan Majemuk. Tangerang: Penerbit Univesitas Terbuka, 2013.

[6] Y. N. Sujiono, Konsep Dasar Pendidikan Anak Usia Dini. Jakarta: PT. Indeks, 2012.

[7] R. Dewi, Pintar Visual Spasial. Jakarta: PT. Wyeht Indonesia, 2004.

[8] U. B. Hamzah, Mengelola Kecerdasan dalam Pembelajaran. Jakarta: PT. Bumi Aksara, 2009.

[9] R. S. Wahyuni, "Upaya Meningkatkan Kecerdasan Visual Spasial Melalui Kegiatan Menggambar Pada Anak Usia Dini Kelompok," Tunas Siliwangi Jurnal Progr. Stud. Pendidik. Guru PAUD STKIP Siliwangi Bandung, vol. 4, no. 1, pp. 38-43, Apr. 2018.

[10] Y. N. Sujiono, Bermain Kreatif Berbasis Kecerdasan Jamak. Jakarta: PT. Indeks, 2012.

[11] Mulyasa, Manajemen PAUD. Bandung: PT. Remaja Rosdakarya, 2012.

[12] M. As'adi, Menghidupkan Otak Kanan Anak Anda. Jakarta: Power Books Publishing, 2009.

[13] T. Gunadi, Optimalkan otak kanan, Otak kiri, Otak tengah, Otak kecil. Jakarta: Penebar Plus, 2010.

[14] L. Asmawati, Dasar-Dasar Pendidikan Anak Usia Dini Secara Islami: Pengembangan Multipotensi dan Multikecerdasan. Jakarta: STIT INSIDA, 2008.

[15] S. Aisyah and D. Novita, Perkembangan dan Konsep Dasar Pengembangan Anak Usia Dini. Jakarta: Universitas Terbuka, 2008.

[16] S. Zaman and A. Libertina, Melejitkan Potensi Akhlak Pada Anak. Bandung: CV Azzam Media Abadi, 2008.

[17] D. Milla and Mas'uda, "Pengaruh Bermain Lego Terhadap Kemampuan Mengenal Warna Pada Anak Kelompok A Di Tk Sabilul Hikmah Surabaya," Jurnal PAUD Teratai, vol. 6, no. 2, pp. 1-4, 2017.

[18] F. Y. Ningtyas, "Metode Bermain Lego Dalam Upaya Menumbuhkembangkan Kecerdasan Kinestetik Pada Anak Usia Dini (Sudi Kasus di Lembaga Pendidikan Manusia Unggul)," Jurnal Empower, vol. 4, no. 2, 2014.

[19] D. A. Maulida, A. T. Hendrawijaya, and N. Imsiyah, "Hubungan Antara Permainan Lego Dengan Perkembangan Kognitif Anak Usia Dini di Play Group Al-Irsyad AlIslamiyyah Jember," Jurnal Edukasi, vol. 5, no. 1, 2018.

[20] K. Ismail, Membongkar Kecerdasan Anak. Jakarta: Gudang Ilmu, 2016.

[21] Wikipedia, "Sejarah Lego." [Online]. Available: https://id.wikipedia.org/wiki/Sejarah_Lego.

[22] M. W. Suzanti, "Hubungan Kemampuan Bermain Balok Dengan Kecerdasan VisualSpasial Anak Usia 5-6 Tahun di TKIT Rabbani,” Jurnal Pendidik. Anak Usia Dini, vol. 5, no. 7, pp. 725-735, 2016.

[23] I.K. Sudarsana, P.W. Renawati, I.W. Nerta, I.K.A. Widana, K. Saddhono, and D. Napitupulu. "The Effectiveness Of Multimedia Training For Elementary School Teachers In Karangasem, Bali." In IOP Journal of Physics: Conference Series, vol. 
1114 no. 1, p. 012032. IOP Publishing, 2018. 